\title{
Between Tradition and Culture:The Status of Muslim Woman in Pre-Jihad Period (1500-1804) inKatsina State, North-West, Nigeria
}

\author{
Dr. Amina Muhammad Sani \\ Al-Qalam University, Katsina - Nigeria
}

\begin{abstract}
The paper is an attempt to understand the role culture and tradition play in the life of the Muslim woman in North-WesternNigeria with Katsina state as a case in point. The paper stresses that under the guise of Islam the Muslim woman has gone through a lot of hardship. This is as a result of the distortions of the teaching of Islam with regards to the position of the woman in a Muslim community. The paper also highlights the fact that the nature of the spread of the religion and misinterpretation of the provision of the Shariah was responsible for relegating the woman to the background and exposing her to oppression.
\end{abstract}

\section{INTRODUCTION}

The paper attempts to examine the position of Muslim woman in a Hausa-Fulani state of Katsina,North Western Nigeria with a view to determining the extent to which her gender as a woman played a role in the status she enjoyed. In examining this role the paper has as its scope the period when Islam became widespread in Hausalandto the beginning of 1804 when the Jihad of UsmanDanfodio broke out. With the outbreak of the jihad it marks the beginning of a new role women were to play in the Hausa states of North Western Nigeria. The period to 1804 will give an insight into the status of women who suffered a lot of deprivation before the advent of the Jihad in Hausaland.The woman in Katsina, like other Hausa states in the northwest geopolitical entity suffered a lot of deprivation. The deprivation was as a result of cultural and traditional manipulation under the guise of religion.

\section{The Position of Women in Islam}

A cursory examination of the position of Islam with regards to the status of women will find that the religion has provided equal role to the woman with that of the man. Her dignity is safeguarded and not subordinated to that of the man. Where they differ with the man is not on the basis of discrimination but on the basis of their psychological differences, which defined the peculiar roles, man and woman should play in a Muslim community. The issue of the position of woman in Islam is distorted by the western propaganda as Abdalati (1982:60) rightly pointed when he opined that:If not because of the impact of foreign cultures and alien influences the issue of the men's position would not even have arisen among the Muslims because the position of woman is taken for granted to be equal to that of man.The irony; however is that it is the western women who did not have their rights enshrined in their religious practices. Whatever position the modern western woman reached it was realized by force or struggle. On the other hand Islam respects and jealousy safeguard the rights of women.It is true that Islam has assigned leadership in the family to the man. This is clearly stated in Quran 4:34 where Allah says:

Men are the maintainers of women because Allah has made some of them to excel others and because they spend out of their property and good women are therefore obedient, guarding the unseen as Allah has guarded and (as to those) on whose part you fear distention, admonish them and leave them alone in the sleeping places and beat them: if they obey you, do not seek away against them. Surely Allah is High, Great.

However, what is clear from the above is that though leadership of the household, is vested in the man, the Muslims are enjoined to lead their homes in mutual consultations with their wives.

From the foregoing Quranic verses it becomes clear that Islam has succeeded in breaking the inferior status women in the pre-Islamic era.The men are not superordinate being over their wives. In fact the prophet (PBUH) had elaborated on the ethical conduct of men towards their wives. This is what the prophet (PBUH) had to say: The best of you is the best to his family and I am the best among you to my family or the most perfect believers are the best of you and those who are best to their wives.Indeed Islam has brought about the liberation and freedom of women from all oppressions. The Quran emphasized that man and woman are two physical forms of the same soul. The Quran 4:11 says: 
O man! Fear your Lord who created you from one soul and out of it created its mate; and out of the two spread many men and women. Fear Allah in whose name you plead for right and need the ties of kinship. Surely Allah is ever watchful over you.

The above Qur'anic injunctions and the Hadith of the Prophet (PBUH) are enough testimonies to refute the notion that man is more honoured for being a man and women as inferior. The segregation has no place in Islam. The rights of women are well entrenched in the shariah. This was why many women became traders, scholars and leaders during and after the death of the Prophet Muhammad (SAW).

\section{The Muslim Woman in Katsina}

In the pre-jihad period the Muslim women in Katsina were in total darkness. The positionis similar to the role of the women of the Arabian jahiliyya period. In all aspects of life women were discriminated. They were deprived of learning. They were no more than objects of enjoyments. They were taught that obedience to husbands in all respects was a must. Womenwere therefore subjected to exploitation, maltreatment. This made their lives unsecure, making them inferior to men. This is why as a result of the wrong interpretation of Islam in the period women were left in a state of complete ignorance of the principles of their religion. There was therefore lack of spiritual guidance which affected woman's duties as a Muslim. The misinterpretation of the role of women in the religion, which resulted in lack of spiritual guidance is as a result of the nature of the people responsible for spreading the religion in Katsina and indeed in the whole of Hausaland.By the $15^{\text {th }}$ century Islam has become widespread in the Hausa states, especially Kano and Katsina(Balogun, 1980). It was spread by traders. However it must be remembered that not all traders were learned enough to convey to their converts more than the rudiments of the religion. Few were also scholars. Therefore though Islam became widespread in our area, knowledge of it was shallow. This was the beginning of the survival of many cultural beliefs associated with Islam. Not surprising therefore that the right of women was taken for granted.During this early period of spread of Islam the religion continued to unite with practices associated with the tradition and culture.

This is because majority of those who spread the religion in Hausaland were traders and not scholars. They spread no more than rudiments of the religion. This was why understanding the religion became superficial. This was why a good number of traditional cults and practices were tolerated or survived among, which was the subjugation of womenfolk. In many cases Islam became assimilated with non-Muslim practices.Suchwas the nature of Islam and the position of women by the $18^{\text {th }}$ century, which attracted reformers in Hausaland.Therefore in describing the condition of women UsmanDanfodiyo in his writings, a prelude to the jihad, said:Some women develop the habit of abandoning prayers after the stop of menses until they wash their clothes. The same attitude was shown by women observing confinement. Despite the stoppage of the blood, they continue to leave in impurity and abandon prayer. According to Sheikh their target was always the forty days ordinance that asked them to take ritual bath and pray whenever the blood stopped even on the day of delivery.In this period in addition to all sorts of deprivation, women were free to mix with men without any restriction, which in many cases led to sexual violence. In his write up, ShehuUsmanDanfodyo described this unrestricted interactions between man and woman, thus:

They assembled at a place with evil intention, he who sees then (at a state) has seen senseless (but itself) men and women though lying down (half naked) in the open each of them with shameless dazzling eyes bulging out. Men and women though keep and clapping their hands, jumping up and down turning sideways staggering.

This was the plight of women in this period where women were in total darkness and experiencing severe subjugation in the hands of men. It was in this period that there emerged a jihadist,UsmanDanfodio, who was able to bring some succor on the condition of women not only in Katsinabut in the whole of Hausaland.In Hausaland, in the pre-jihad period, oppression was rampant affecting all citizens but the suffering of women was more severe because they were women. This is why as a result of the lopsided interpretation of Islam in the period women were no more than second hand citizens. Then could suffer compulsory marriage. They could also be divorced even with flimsy excuses. This domination of women, which had no basis in the shariah continued unabetted. Because of the ignorance of the period and the nature of the scholars this subordinate role given to women was given religious colouration. The misinterpretation of the role of women in the religion, which resulted in lack of proper spiritual guidance, is as a result of the nature of the spread of the religion in the area.The reality however was that this role given to women has been found to be based on the old cultural beliefs which had its basis from the nature of the spread of the religion in our area. By the $15^{\text {th }}$ century Islam as mentioned earlier has reached the Hausa states and widespread in Kano and Katsina. It was spread by traders. This traders were not learned enough to convey to their converts more than the rudiments of the religion. Few of these traders were scholars. Therefore though Islam became widespread in our area knowledge of it was shallow. This was the beginning of the survival of many cultural beliefs associated with Islam. Not surprising therefore the rights of women were taken for granted. During this early period of spread of Islam up to the 
outbreak of the $19^{\text {th }}$ century jihad in Hausalandthe religion continued to be united with practices associated with tradition and culture.

\section{CONCLUSION}

In the foregoing there has been an attempt to examine the plight of women in this period where women were in total darkness and experiencing severe subjugation from men. It was in this period, $18^{\text {th }}$ century,that there emerged a jihadist, UsmanDanfodio, who was able to bring some succor in the condition of women not only in Katsina but in the whole of Hausaland.

\section{REFERENCES}

[1] Abdalati, H. (1982), The Family Structure in Nigeria.Lagos: Islamic Publication Bureau.

[2] Al-Hajj, M. A. (1995), "The meaning of Sokoto jihad", Usman Y. B. (ed.) Studies in the history of the Sokoto caliphate. Lagos: Third Press International.

[3] Ali, A.Y (1988), Modern English Translation of the Glorious Quran. Meaning and commentary.Kausas City, USA: Manner international.

[4] Aliman, J. (1978), Women's Status and Fertility in the Muslim World. New York: Praeger Publishers,

[5] Balogun, S. A. (1980), History of Islam up to 1800', Ikime, O. (ed.)Groundwork of Nigerian History. Nigeria: Heinemann Educational Books.

[6] Ismail, M. H. (nd) Sahih Al-Bukari Vol. 1 Dar Al-Arabia Beirut.

[7] Muslim, H. (nd) Sahih Muslim (Trans) VOl. 2, DarelManer Publishers

[8] Nguru, M. M. and Liman, S. H. (2012) Shariah and the Defence of Women's Rights. Nigeria:

[9] LihiCorypheesNguru.

[10] The Qur'an Arabic Text with corresponding English meaning. Edited by Saheeh International AbulQasim publishing House 1997 (Al-MuntadaAlislami) 